\title{
Depicting community perspectives: repeat photography and participatory research as tools for assessing environmental services in Sagarmatha National Park, Nepal
}

\author{
Rodney Garrard, Thomas Kohler, Urs Wiesmann, Martin F. Price, Alton C. Byers \& Ang Rita Sherpa
}

Keywords: perceptions, qualitative methodology, photo-interviewing, UNESCO World Heritage Site, protected mountain areas, conservation, livelihoods, human well-being

\section{Abstract}

Efforts have been made to provide a scientific basis for using environmental services as a conceptual tool to enhance conservation and improve livelihoods in protected mountain areas (MtPAS). Little attention has been paid to participatory research or locals' concerns as environmental service (ES) users and providers. Such perspectives can illuminate the complex interplay between mountain ecosystems, environmental services and the determinants of human well-being.

Repeat photography, long used in geographical fieldwork, is new as a qualitative research tool. This study uses a novel application of repeat photography as a diachronic photo-diary to examine local perceptions of change in ES in Sagarmatha National Park. Results show a consensus among locals on adverse changes to ES, particularly protection against natural hazards, such as landslides and floods, in the UNESCO World Heritage Site.

We argue that our methodology could complement biophysical ecosystem assessments in M+PAS, especially since assessing ES, and acting on that, requires integrating diverse stakeholders' knowledge, recognizing power imbalances and grappling with complex social-ecological systems.

Profile

Protected Area

Sagarmatha National Park

Mountain range

Himalaya

Country

Nepal

\section{Introduction}

Mountain ecosystems provide many environmental services (ES): protection from natural hazards, water provision and regulation, food and fibre production, and scenic beauty (e.g. Körner \& Ohsawa 2005). ES are defined as functions of ecosystems with value for human well-being (Costanza et al. 1997; MA 2003, 2005). To assess their provision, we must understand the interdependencies between the ecological and socio-economic systems. ES supply in mountain areas is sensitive to climate and land-use changes; placing mountain ecosystems under pressure (e.g. Grêt-Regamey 2007).

While human activities have strongly modified Himalayan ES provision for centuries (e.g. Smadja 2009), the Khumbu region (or SNPBZ - Sagarmatha National Park and Buffer Zone; Figure 2) has changed rapidly in recent years (e.g. Byers 2005; Stevens 2003). Global market economy, political changes, and tourist demand have affected the relationship between Sherpas and their environment (e.g. Nepal et al. 2002; Sherpa 1998), as shown by many repeat photographs (e.g. Byers 2005).

Himalayan case studies reveal overexploitation, fragmentation and degradation (e.g. Chaudhary et al. 2007). These impair the ecosystems' ability to provide ES, which affects human well-being (e.g. TEEB 2010). The concept of ES is gaining recognition (e.g. Daw et al. 2011; Naidoo et al. 2008) as a way to protect ecosys-

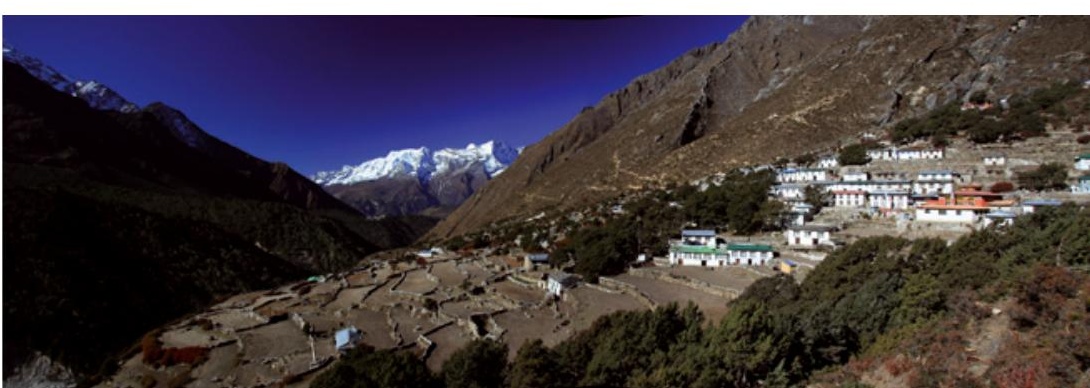

Figure 1 - Pangboche in the Sagarmatha National Park. (C) R. Garrard

tems and improve the livelihoods of people who use and deliver ES (e.g. Chan et al. 2006).

Efforts have been made to provide a scientific basis for using ES for conservation in specific mountain areas (e.g. Grêt-Regamey 2012; Rasul et al. 2011), but little attention has been paid to participatory research or locals' concerns as ES users and providers (Zilberman 2007), especially in the Himalayas, where global development threatens ecosystems and local dependence on ES is high (e.g. Turner et al. 2012). Such knowledge is essential for effective approaches to ES providers, often highlighting entrenched power dynamics (Galvin \& Haller 2008).

ES are the benefits people get from ecosystems goods (e.g. food, timber) and services (e.g. nutrient cycling) (Costanza et al. 1997; MA 2003). The Millennium Ecosystem Assessment (MA) classifies ES as:

- provisioning services: products obtained from ecosystems; 


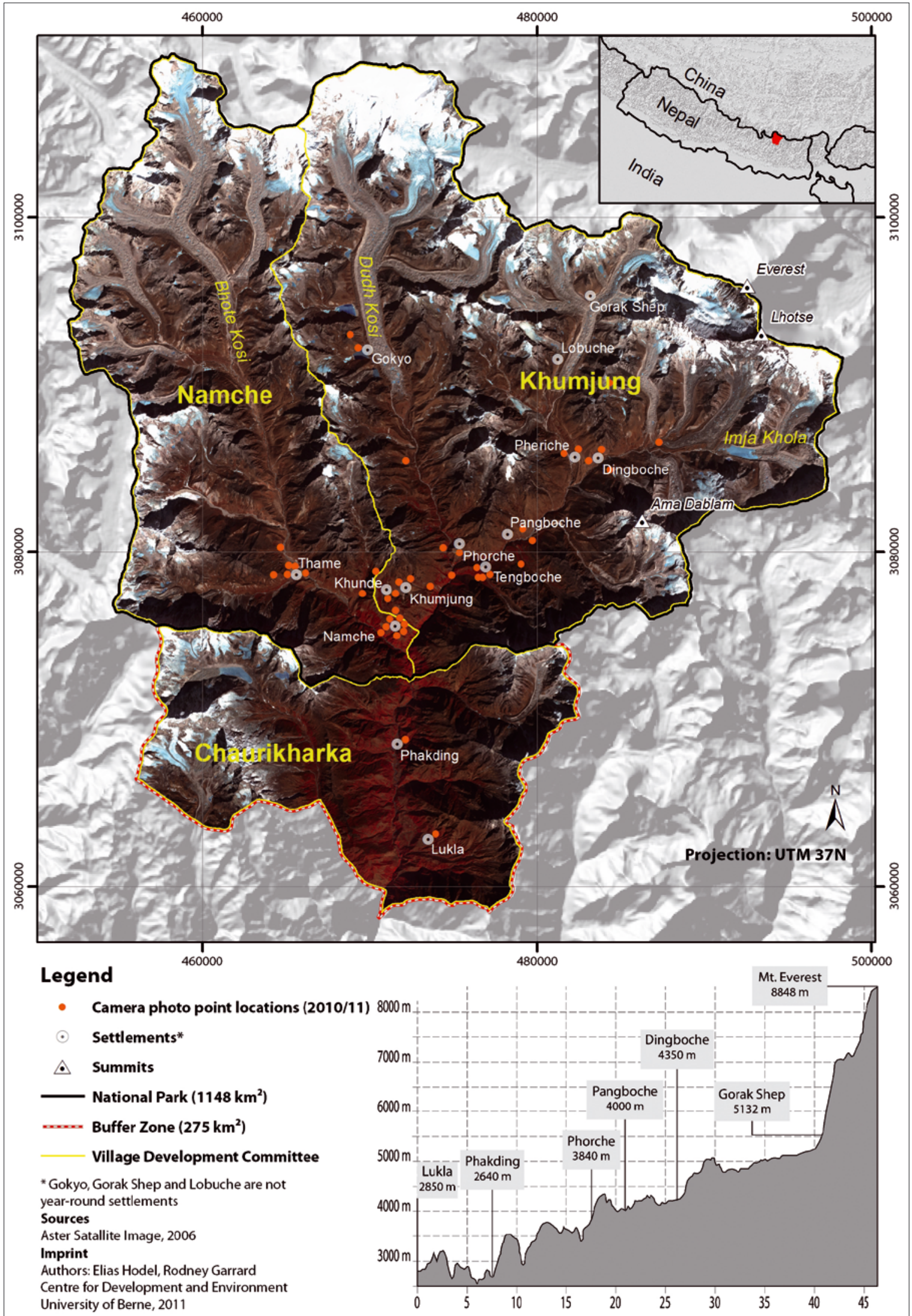

Figure 2 - Sagarmatha National Park and Buffer Zone (SNPBZ) 
- cultural services: non-material benefits obtained from ecosystems;

- regulating services: benefits obtained from the regulation of ecosystem processes;

- supporting services: services necessary for the production of all other ecosystem services.

It is important to recognize that mountain ecosystems are highly multi-functional. Because benefits of services accrue to both mountain and lowland populations, the term environmental services is used in this paper to apply the concept to a wide range of application domains outside of a particular ecosystem and thus arguably more comprehensive in scope. Although the four ES categories above are generally well accepted in the literature, the services themselves are often not well articulated (EEA 2010) and their simplicity is deceiving - so much so that some have begun to doubt the utility of ES in practice (e.g. Grêt-Regamey 2012). As such, Table 2 defines selected ES used in this paper to illuminate the findings better.

This article presents and tests a method to examine local perceptions of change in relation to selected ES: food, fodder, water provision, aesthetic landscape, timber and protection from natural hazards (Table 2). This article has two goals: first, a community-level assessment of ES, revealing the interplay between ecosystem functions, ES and human well-being (e.g. Carpenter 2009; Daw et al. 2011). We use the concept of ES (MA 2003) as the entry point and repeat photography as photo-elicitation (e.g. Harper 2002) to understand factors by which locals assess changes to specific ES.

Second, the article seeks to evaluate whether repeat photography as diachronic photo-interviewing is an efficient way to identify local changes in ES. Repeat photography - comparing historical and recent photographs from the same location - is rarely used as a qualitative inquiry (e.g. Harper 2002; Nüsser 2001; Webb et al. 2010) into socio-economic and cultural processes around environmental change.

\section{Case area}

SNPBZ is in the Solu Khumbu district of northeastern Nepal (Figure 2). SNP covers $1141 \mathrm{~km}^{2}$ and was designated a UNESCO World Heritage Site in 1979. In 2002, the $275 \mathrm{~km}^{2}$ Pharak region to the south was declared as the park's buffer zone (BZ). Altitudes range from $2850 \mathrm{~m}$ (Lukla) to $8848 \mathrm{~m}$ (Mt Everest).

SNPBZ is administered by three village development committees (VDCs) (Figure 2), which function as administrative institutions for interacting with national institutions in Nepal, thus creating an element of local control and responsibility in development.

SNPBZ has been shaped by ca. 400 years of human use (Stevens 2003). Recent changes are shown by many repeat photographs (e.g. Figure 3). Satellite images show dramatic changes in higher mountain environments, with new lakes and retreating glaciers (Bajracharya et al. 2007; Mool et al. 2001). While there have been claims of contemporary forest and general environmental degradation in the region, studies by Stevens (2003) and re-photography by Byers (1997) report a relatively intact landscape in the lower regions.

We argue that using repeat photography as a diachronic photo-diary could complement biophysical ES assessments in protected mountain areas, especially since assessing ES, and acting on that, requires integrating diverse stakeholders' knowledge, recognizing power imbalances, and grappling with complex socialecological systems.

\section{The photographic record}

Considering SNPBZ's remoteness, its historic photographic record is surprisingly rich. Between 1954 and 1963, Austrian and German geographical expeditions visited the region, providing an unprecedented, systematic collection of historical photos (Byers pers. comm. 2009), most of which show land-use and settlement patterns. Further images were sourced from the Royal Geographical Society and the National Library of Scotland, covering SNPBZ as part of 1950s Everest expeditions, and from private collections of historical photos (Table 1).

Table 1 - Historical photographs from archives and museums, individuals and published sources in SNPBZ.

* Photo archives from Arbeitsgemeinschaft für Vergleichende Hochgebirgsforschung and Österreichischer Alpenverein

\begin{tabular}{|l|l|l|}
\hline Archive - Collection & Year(s) & URL/contact \\
\hline The Royal Geographical Society (UK) Everest collection & $1951 / 53$ & $\begin{array}{l}\text { http://images.rgs.org/ } \\
\text { (accessed 18.06.2011). }\end{array}$ \\
\hline The National Library of Scotland (Edinburgh, UK) - Tom Weir's estate & 1952 & $\begin{array}{l}\text { http://www.nls.uk/ } \\
\text { (accessed 18.06.2011). }\end{array}$ \\
\hline $\begin{array}{l}\text { ICIMOD (Kathmandu, Nepal) photo repository*, including photo- } \\
\text { graphs by Prof. Jack Ives (Canada) }\end{array}$ & $1950 / 56 / 61$ & $\begin{array}{l}\text { http://www.icimod.org/changing-landscapes/ } \\
\text { (accessed 08.08.2011) }\end{array}$ \\
\hline $\begin{array}{l}\text { Dr. Alton Byers, TMI, (US) personal archives* } \\
\text { Prof. Helmut Heuberger (Österreichischer Alpenverein), personal } \\
\text { archives }\end{array}$ & $1974 / 84 / 95 / 98$ & $\begin{array}{l}\text { http://www.mountain.org/staff } \\
\text { (accessed 08.08.2011) }\end{array}$ \\
\hline $\begin{array}{l}\text { Norman Hardie (New Zealand Alpine Club), personal archives } \\
\text { http://www.alpenverein.at/portal/index.php } \\
\text { (accessed 08.08.2011) }\end{array}$ & $\begin{array}{l}\text { http://alpineclub.org.nz/ } \\
\text { (accessed 08.08.2011) }\end{array}$ \\
\hline Bruce Jefferies (New Zealand), personal archives & $\begin{array}{l}\text { http://protectmountains.org/ } \\
\text { (accessed 08.08.2011) }\end{array}$ \\
\hline Fritz Müller's estate, provided by Giovanni Kappenberger (Switzerland) & 1956 & \begin{tabular}{l} 
(accessed 30.11.2011) \\
\hline
\end{tabular} \\
\hline
\end{tabular}



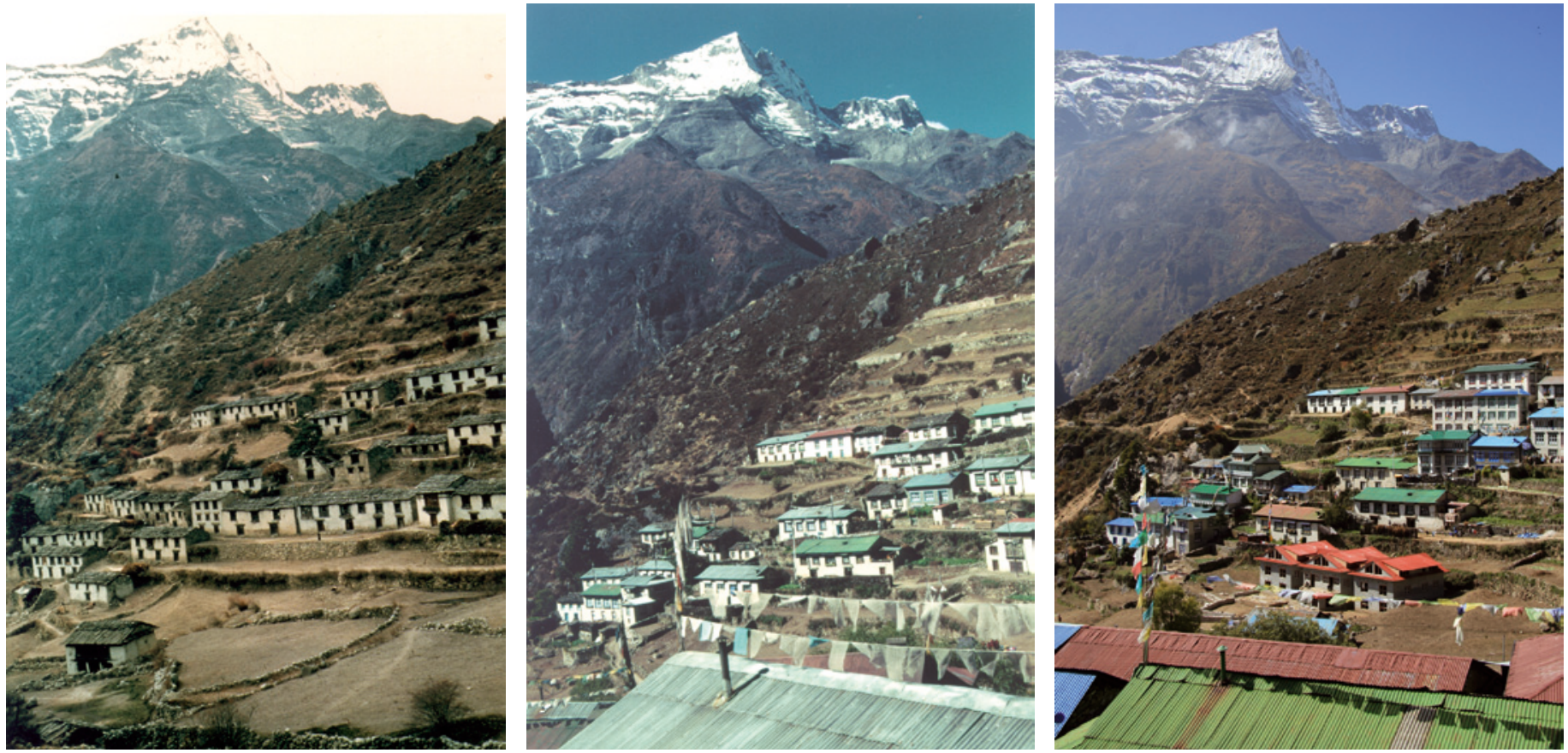

Figure 3 - left to right: Namche 1950, (C) C. Houston, courtesy of A. Byers; Namche 1995, (C) A. Byers; Namche 2010, (C) R. Garrard.

The photographs referenced above were used in a diachronic photo-diary (143 side-by-side images) from both the cultural and natural resource perspective over nearly six decades. We re-located selected viewpoints and produced a set of replicates, chosen to show typical and representative examples of the region (Figure 3) and to include all 3 VDCs (Figure 2) of SNPBZ.

\section{Methodology}

A case study approach (de Vaus 2001) was used to examine perceptions of change in relation to selected ES. The study was based on qualitative interviews as these provide detail on concepts relevant to research participants - important given the unfounded generalizations of past environmental change in SNPBZ.
Purposive sampling (selecting a sample that can provide the most relevant and insightful information) (Henderson 1991) was used to identify suitable persons to be interviewed. These were of two general types.

Criterion 1: participants, who were thought by resource persons (e.g. key informants, network referrals and local research assistants) to demonstrate a willingness to co-operate with researchers and possess good communication abilities; and Criterion 2: resource persons were asked to recommend community members concerned about current and future conditions of the region's development, and who play an active role in expressing their concerns through formal channels (buffer zone committees etc.), as well as informal channels of communication (local women's groups etc.).

Table 2 - Ecosystem services (ES) examined. * Supporting services are associated with the underlying ecosystem functions that sustain all other ES (e.g., nutrient cycling)

\begin{tabular}{|c|c|c|}
\hline MA category & ES & components \\
\hline \multirow[t]{6}{*}{$\begin{array}{l}\text { Provisioning } \\
\text { services }\end{array}$} & Food crops & $\begin{array}{l}\text { We define agricultural services as contributions towards food crops and fodder by both intensive and traditional farming meth- } \\
\text { ods. Despite limited cultivated land, agro-pastoralism has been central to the Sherpa's livelihood. }\end{array}$ \\
\hline & Fodder & noted above \\
\hline & Timber for firewood & SNPBZ is a major wood provider. We define services from the forests as fuel wood, building timber and non-timber products. \\
\hline & Timber for building & $\begin{array}{l}\text { The forests of SNPBZ provide raw materials for building use. For this study we did not exclude timber as a raw material from } \\
\text { south of the Park also because of conservation polics. }\end{array}$ \\
\hline & Non-timber & We define non-timber services as wild plants harvested for consumption and for sale. \\
\hline & $\begin{array}{l}\text { Water provision } \\
\text { (quantity) }\end{array}$ & $\begin{array}{l}\text { Water is unique as an ES in SNPBZ: it delivers provisioning, regulating and cultural services. Fresh water is consumed for drink- } \\
\text { ing and sanitation, and used to produce food and energy and to recharge reservoirs. Its aesthetic and spiritual values are also } \\
\text { appreciated. }\end{array}$ \\
\hline \multirow[t]{3}{*}{$\begin{array}{l}\text { Regulating } \\
\text { Services }\end{array}$} & $\begin{array}{l}\text { Water provision } \\
\text { (quality) }\end{array}$ & Mountain biodiversity (e.g. plants, soil) prevents deterioration of water and supports rehabilitation of water sources. \\
\hline & $\begin{array}{l}\text { Protection from } \\
\text { landslides }\end{array}$ & High mountain landscapes like SNPBZ are especially vulnerable to landslides and need improved risk reduction (Hewitt 2009). \\
\hline & Protection from floods & Mountains regulate water flow by storing water and modulating the run-off regime and ground water seepage. \\
\hline \multirow[t]{2}{*}{$\begin{array}{l}\text { Cultural } \\
\text { services }\end{array}$} & $\begin{array}{l}\text { Aesthetic landscape, } \\
\text { tourism and recreation }\end{array}$ & $\begin{array}{l}\text { Mt Everest is such a tourist focal point, we consider it an ES in itself. Scenic beauty, ruggedness and tranquillity are the main } \\
\text { reasons for visiting SNPBZ (HKKH 2010). Tourism is the most important source of earning for Sherpa people. }\end{array}$ \\
\hline & $\begin{array}{l}\text { Culture, sense of } \\
\text { place }\end{array}$ & $\begin{array}{l}\text { SNPBZ is a Beyul, a Sherpa sacred place and a place of pilgrimage and religious tourism. There are many sites of archaeologi- } \\
\text { cal and vernacular interest. }\end{array}$ \\
\hline
\end{tabular}


We also used theoretical sampling (Hunziker et al. 2007) in finding contrast among interviewees. For example, for this paper ages were selected to cover perceptions from at least the 1970s to the present.

46 locals were interviewed as part of two field visits to the nine major villages inhabited all year (Figure 2).

Interviews were in-depth, semi-structured and lasted 1-4 hours. We assessed the sample's sufficiency via Lincoln and Gruba's (1985) guideline for ending data collection: the appearance of regularities in the data. We pre-tested questions with three resource persons to ensure clarity and relevance.

In each interview, we presented a diachronic photodiary in conjunction with topographical maps. The photo-diary helped researchers and participants elucidate difficult concepts (and questions) that might otherwise have been difficult for both the researcher and the participant to articulate.

We began by discussing participants' perceptions of changes over time, then changes in selected ES (Table 2). Interviewees ranked the degree of change on a 7 -point Likert scale from -3 (negative change) to +3 (positive change) for each ES, Figure 4. Interviews were subjected to qualitative content analysis (Hay 2000). Further data collection methods included a review of documentary material, attending community events and meetings, and accompanying resource persons on walking tours of picture locations.

\section{Results}

Interviewees in all VDCs outlined negative changes in regulating services (protection from landslides and flooding) and provisioning services (firewood.) Changes in cultural services (aesthetic landscape) and provisioning services (building timber) were seen positively, if of value for tourism, or negatively, if at odds with local values (e.g. access to forests). According to Sherpa value systems (e.g. nawa, di, simback: local customary management systems), low-income farmers tended to perceive change in terms of losses or gains in provisioning services, while more affluent individuals valued cultural services for tourism potential (e.g. lodge construction). All VDCs reported positive changes to water provision, primarily due to the fact that access to safe drinking water has improved for most dwellings in SNPBZ. The perceived rate of change appeared not to affect positive or negative valuation of changes in ES.

Consistent with perception research in human geography (Hay 1998; Kruger 2005; Shindler et al. 2002), participants associated multiple values with their environment and made complex evaluations of multiple impacts of change to specific ES. It was difficult to gauge whether the participants carried out multicriterion analysis. However, the complexity of their evaluations and effort to consider multiple ES within the context of a single response is illustrated by the following comment:

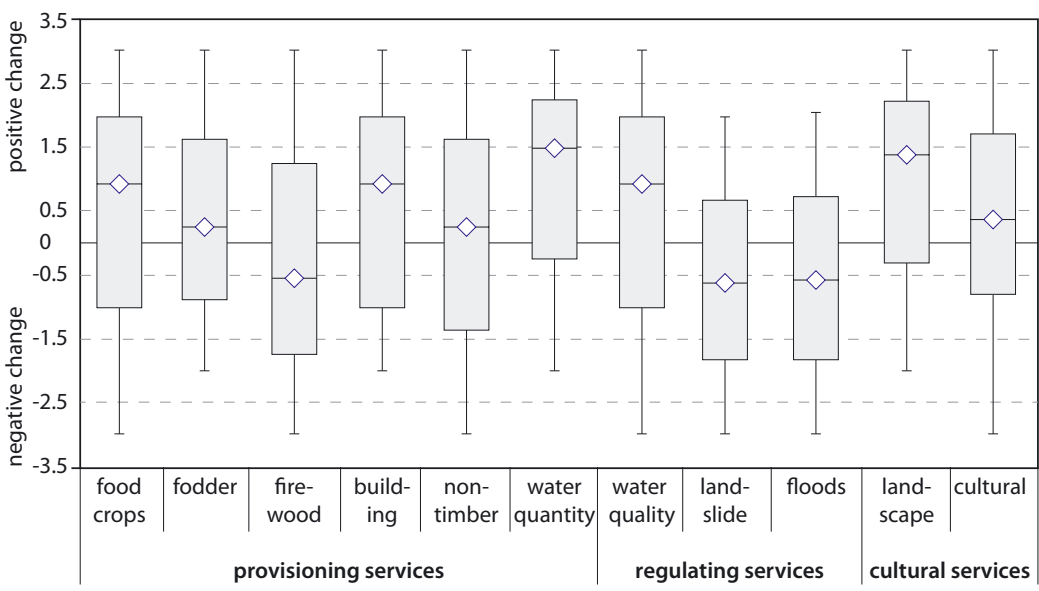

Figure 4 - Perceptions of change in relation to selected ES in SNPBZ; the Likert assessment mean, $75 \%$ quartile, and ranges are shown. $(N=46)$

Interviewee (I) 1: That's what strikes me about these photographs (diachronic photodiary: Namche), the different colours of the roofs are not very cosmetic. It looks a bit like the discarded oxygen cylinders at South Col (Everest). The vegetation has increased here (referring to the slopes above Namche) but still these areas are prone to erosion and flooding. Before, we used to have lots of seepage into the water springs, and stuff like that ... and, here (diachronic photodiary: Phorste), this is a nice example of a protected forest since way back ... it's good for the wildlife, good for musk deer ... Yeah, there's other values in these forests besides the timber.

Different ES clearly had distinct collective meanings as well as different meanings for individuals. These meanings are driven by collective or individual value systems, especially for cultural services (e.g. gombas monasteries) specific to villages and for provisioning services (e.g. grazing areas and forests).

I 2: ... it's cultural in that we Sherpas have through generations made use of the forest resources. I think it's important that we continue to have access to those values ... Our culture and religion have always played an important part in the conservation of nature and still do. Now, the power to decide what is best for our forests has been taken away by the Government and Dept. of National Parks, which has caused more chopping and cutting of trees.

Sherpas approach the local environment with sophistication in the breadth of issues they consider and highlight particular types of ES with aspects of their well-being. Any successful ES management will need to include local circumstances, prior land-use history, and the socio-economic and cultural context of changes in ES. Table 3 summarizes the main ES changes perceived across the study area.

\section{Food crops and fodder - provisioning services}

$53 \%$ of participants say maintaining traditional agro-pastoral livelihoods is getting harder. $67 \%$ blame demographic and economic factors (increased tourist demand, reduction of Sherpa workforce); $21 \%$ blame 
intensification of production factors (chemical fertilizers, new seed types, irrigation, greenhouses):

I 3: Before we used tho (tuber crop) for making our food but now people are throwing it away. When I was young, I went to the lowlands to work in the fields but now they are coming here into our village. Instead of planting barley and buckwheat, people today are cultivating potatoes. The production methods are fast, giving fast cash. Nowadays people have more money, more income and we can buy a variety of food from the lowlands to eat.

I 4: The numbers of livestock in this village have decreased by $75 \%$. Before, one household would own about 40-50 cattle, but now I know of only one man who owns 40 yaks and the other households have only a few heads of cattle. Some have sold them altogether. This is because of a decrease in fodder in the grazing lands, there's also the problem of the snow leopard prey on the cattle, need a person to look after them and it's just not possible with tourism today.

In addition, $14 \%$ of interviewees mentioned a recent decline in the quantity of cash crops like potatoes.

So provisioning services from which Sherpas derive their livelihoods are changing. Most think these changes are positive (Figure 4) but are worried about recent climate variability, one of the most pervasive stresses to mountain livelihoods (Zierrogel \& Calder 2003).

\section{Firewood and timber - provisioning services}

National Park conservation policies are seen as failing to balance local well-being, conservation and development. The negative assessment of ES change (Figure 4) pertains to access to forest resources; current conservation policies ignore local cultural factors: I 5: We used to manage the collection of firewood within the community through our shinngi nawa (timber use tradition). We would rotate collection days per household and we could collect from anywhere around this area here ... Today, these areas for collection have been reduced because of the nation- al park. Now we are only allowed to collect twice a year (for) 10 days and we feel that next year it will be five days and then no access at all ... It's fine for those lodges that can afford alternative resources (e.g. gas, kerosene), but for the poorer households this is a big concern now.

Since 1979, the SNP Forestry Programme has planted about 2 million seedlings in the region (Gurung et al. 2010). Bajracharya et al. (2010) show that between 1996 and 2006, deciduous and coniferous forests increased by $7.2 \mathrm{~km}^{2}$ and $2.8 \mathrm{~km}^{2}$ respectively. Yet only $36 \%$ of the participants believe the forest situation has improved and $14 \%$ report degradation of the forest.

Water as a provisioning, regulating (and cultural) service

$81 \%$ of participants say water provisioning is better (Figure 4). Virtually $100 \%$ of the park's population now has safe drinking water, compared with Nepal's average of $78 \%$ (NPC 2011). However, 66\% think winter snow has decreased, and 51\% said monsoon rains are now heavier but shorter. This is corroborated by studies (IPCC 2007):

I 6: I do worry about the droughts in the spring... Before, it used to snow to a height of 4 feet or more, nowadays, a heavy snow is 1.5 feet on the ground. This has been occurring over the last $4-5$ years. Due to less snow, the amount of water is much less.

This and increased demand are affecting water supply in five of the villages, although two (Khumjung / Kunde) have suffered from droughts since historical times.

$7 \%$ of participants noticed drier periods in streams; $22 \%$ mentioned reduced glaciers and snow in the high mountains, a threat to communities that depend on melt water:

I 7: Today it rains less and the amount of snowfall has also decreased a lot ... When I was a boy, Imjatse (Island Peak) used to be covered in snow, today it is a rocky mountain. I am worried about future water supplies as a result of less snow on the likes of Imjatse.

Table 3 - Summary of main changes to ES with SNPBZ. * Prospective, the rest retrospective

\begin{tabular}{|c|c|c|}
\hline Selected ES & Main themes & Explanation \\
\hline $\begin{array}{l}\text { Provisioning services } \\
\text { (food crops, fodder, } \\
\text { timber for firewood } \\
\text { and building, and non- } \\
\text { timber products, water } \\
\text { quantity) }\end{array}$ & $\begin{array}{l}\text { Increased sustenance and income from } \\
\text { crops. Declining traditional agro-pasto- } \\
\text { ralism system and assoc. socio-cultural } \\
\text { change. Forests cherished for multiple } \\
\text { values. Improved access to water; increas- } \\
\text { ing water shortages* (with exceptions) }\end{array}$ & $\begin{array}{l}\text { Cash crops are seen as a positive source of income and consumed locally. However, } \\
\text { participants are worried about declining yields \& fertilizer use. Loss of traditional } \\
\text { crops with cultural connotations. Livestock are losing their dominant economic status, } \\
\text { but there are concerns about having less grazing space and fodder. Reforestation, } \\
\text { esp. along river banks, is viewed as beneficial, reducing erosion and flood damage. } \\
\text { Residents are worried about the impacts of climate change on future water supplies*. }\end{array}$ \\
\hline $\begin{array}{l}\text { Regulating services } \\
\text { (protection from } \\
\text { landslides and flooding, } \\
\text { water quality) }\end{array}$ & $\begin{array}{l}\text { More landslides and erosion, and intense } \\
\text { rainfall events, becoming more severe. } \\
\text { Overall, less rainfall and erratic, water } \\
\text { sources becoming contaminated (with } \\
\text { exceptions) }\end{array}$ & $\begin{array}{l}\text { Landslides ( } \& \text { erosion) and flooding (e.g., Glacier Lake Outburst Floods [GLOFs])* } \\
\text { worry residents, who associate them with increased rain/flooding and climate } \\
\text { change, leading to environmental uncertainty, risk and material loss. The forest } \\
\text { capacity may be less able to absorb intense rainfall events. Streams \& lakes con- } \\
\text { taminated by untreated grey water, lodge infrastructure (untreated toilets), pesticide/ } \\
\text { fertilizer use, and livestock. }\end{array}$ \\
\hline $\begin{array}{l}\text { Cultural services } \\
\text { (aesthetic landscape \& } \\
\text { culture as a sense of } \\
\text { place) }\end{array}$ & $\begin{array}{l}\text { The multiple value of landscape features } \\
\text { (e.g. Mt Everest), inappropriate conserva- } \\
\text { tion policies, inflation, infrastructure es- } \\
\text { sential for livelihoods, changing functional } \\
\text { arrangements of villages as civic places, } \\
\text { concern about in-migration and changes } \\
\text { in social relations and cultural institutions }\end{array}$ & $\begin{array}{l}\text { Participants identified cultural functions of ES related to tourism (esp. Mt Everest) and } \\
\text { the area's aesthetic beauty, but were critical of conservation policies and worried } \\
\text { about the declining integrity of SNPBZ*. Participants boasted about their natural } \\
\text { surroundings and the range of benefits they derived from their environment, but are } \\
\text { concerned about fair distribution of income from tourism. }\end{array}$ \\
\hline
\end{tabular}


$92 \%$ of interviewees said the water has always been of very good quality, in contrast to this report:

"Water sources along the major trails are being contaminated by improper affluent discharge, human waste and garbage dumping. Sewerage and toilet waste can be found piped into nearby streams and rivers." (SNPBZ Management Plan 2006: 46).

The uncertainties about the relationship between precipitation, watershed functions and land-use changes in SNPBZ need further exploration.

\section{Landslides and floods - regulating services}

$75 \%$ of participants worried about changes to regulating services: rivers flooding, landslides and erosion due to land-use change. Periodic flooding (e.g. glacial lake outburst floods, GLOFs) of the rivers also worries residents. Most interviewees were aware of recent landslides and flooding. 90\% observed and/or suffered from the Dig Tsho GLOF event of 1985. Furthermore, 16\% could recall the Ama Dablam GLOF of 1970, and much discussion surrounded a possible GLOF from Imja Tsho Lake in the future.

I 8: The bridges seem to be washed away as a regular occurrence these days - particularly during monsoon. But no NGOs help with the funding for the construction of new bridges.

I 9: Today there are more landslides because of the heavy monsoon rains. It's affecting farming as there is an increase in sand and this affects the productivity. In Dingboche, close to the Imja Glacier (Figure 2), participants fear an Imja GLOF.

I 8: In this village the people are afraid, but on the whole they have faith that the pujah recently carried out at the Imja (lake) to prevent a GLOF will keep us safe, even though the area where the pujah was conducted has itself collapsed in the lake.

With predictions of more intense rain (IPCC 2007), and more building in high-risk zones, landslides and floods are likely to accelerate.

\section{Aesthetic landscape and culture - cultural services}

Participants are positive about cultural services (e.g. aesthetic landscape), especially lodge development, for its tourism potential (Figure 4), but 27\% worry about the deteriorating environment:

I 10: Look at these changes here (diachronic photodiary: Gokyo), even in this remote place it looks like a city ... In all of the valleys are cities these days ... The way we live nowadays - it's not natural.

$17 \%$ of participants thought tourist income was not fairly distributed and $52 \%$ thought the significant change in SNPBZ was inflation. The question is how to reconcile mountain ecotourism and environmental protection to ensure ES provision, and how to promote true tourism partnerships with local communities.

Sherpas' perception of their villages is changing; lodges have replaced gombas (monasteries) as community halls:
I11: This village has changed - look across the river, that's the new centre - the lodges with the big windows. The land price over there has increased a lot. It's by the main trekking trail ...

Some lodges are now intimately linked with religious places and practices. Gombas may be losing their central role in civic life.

$73 \%$ of participants are concerned about recent inmigration of lowlanders:

I 12: When I look at these photos, we have lost so much, everything has changed. Before, we had small houses and no airports. Now with tourism and becoming famous, and having more sources of earning, everything has a price in today's life, even stone and sand ... Many people from the lowlands are coming in but they don't follow the cultural traditions. Although there is too much development and many changes, we Sherpas still follow our culture and traditions.

I 13: We are losing our culture and language. Tourism has not had that big an effect but a slight effect. The schools are responsible for the loss of traditional language as well as clothing, because the school's students only learn modern things there ... Because of the media, we know more of other cultures than our own. We never used to celebrate Dashain (National Hindu festival). The pressure from the (Hindu) Government is having an effect on the culture of the local people.

Despite this, many showed strong affection for their village. They are proud of being Sherpas and of being part of the area, which reflects the positive assessment of this ES (Figure 4). They have a strong interest in maintaining cultural traditions.

\section{Discussion}

While we feel we attained a good overview of how Sherpas perceived ES change, we found perceptions varied based on where participants lived and their relationship with the land. The sample is relatively small, so results cannot be statistically generalized, and the semi-structured qualitative process and the diachronic photo-diary may have inadvertently influenced responses. However, measures were taken to reduce this possibility: participant-reviewed transcripts, repeated examinations of interview transcripts, the disclosure of the interview questions, and no obvious bias in the questioning.

This paper has posed a question that is both empirical and methodological. Empirically, the study suggests a number of perceived trajectories of change.

First, in all SNPBZ VDCs, adverse changes in regulating services (landslides and flooding) are worries, showing analytic generalizability (Hay 2000) with other participatory assessments in the region (e.g. Gurung 1989; Oven et al. 2008; WWF 2008). This underscores the need for a risk assessment and reduction programme based on improved understanding of local 
priorities and better dissemination of risk findings to local stakeholders.

Second, the interviews demonstrate that multiple factors affect perception of local ES change. ES are not produced in a straightforward manner and are interrelated. The complexity of the evaluation of specific ES is testament to this, reflected in participants' attention to the visual photo-diary and attachment to natural resource governance and its effect on their communities.

Finally, most interpretations of ES change carried an evaluative weight, often dualistic and rooted in each participant's values. This coloured the Likert scale assessment and directed stakeholders to focus on aspects that a more systematic assessment might ignore, particularly with regard to water provision assessment. There is much speculation on the climate change / water availability nexus and its impacts on mountain communities. These results show climate change may only be one component, and not necessarily the most important, affecting their livelihoods in terms of water quantity, at least in the short-term.

The perceived ES changes tally with case studies of incipient mountain transition (e.g. Chaudhary 2007) where increasing populations and a rapidly changing economy struggle to cope with a competitive commercial market (tourism) and cannot assure sustainable development and resource management. Mt Everest is such a focus for tourism that we consider it a unique ES. However, interviews show that despite SNPBZ's progressive image, benefits from this ES are not fairly shared with residents. Unless policies change, the region's sustainability is threatened.

These empirical results go some way to answering the methodological question: can this be an effective method to survey localized ES change? As seen above, it provides useful empirical results with valuable insights into the relationship between ES and human well-being. It has clear advantages over remote sensing and aerial photograph analysis.

In particular, the photo-diary allowed participants to discuss what mattered most to them, not to the researcher, and to assess positive as well as negative change. This aspires to be a first step in influencing conservation policies in SNPBZ towards broader participation for locals. Our methodology is compatible with the goals of transdisciplinary research (Hurni et al. 2010): to reduce power differentials, build trust and create a sense of ownership. Processes like photo-interviewing create critical dialogue on issues important to residents and could encourage community self-organisation.

Last, we must address the adequacy of the methodology as a participatory research tool in the assessment of ES. Combining narratives with photographs and in situ assessment of ES was very successful. However, important aspects of environmental integrity (e.g. supporting services) are hard to capture in the photodiary, as are dynamic relationships between ecological functions. Nüsser (2001) points out that it is important to consider not just what is in the photograph but also what is not.

Likewise, there are limitations in the use of ES as an entry point, since they are a western construct; Sherpa participants did not talk about provisioning and regulating services per se, but rather the benefits, meanings and values of these ES for their well-being and for their livelihoods.

Finally, the use of a Likert scale worked satisfactorily; presenting such results could be misconstrued unless complemented with evidence of a different kind. In many repeat photography studies, some form of triangulation is used (e.g. land-use and land-cover (LULC) assessment). We will now undertake an integrated assessment of LULC using these metrics and meanings to elucidate the dynamics of ES (Garrard et al. in prep).

\section{Conclusion}

Repeat photography using a diachronic photo-diary as applied in this study is a useful way to gain an insight into localized changes in the provision of ES. It allows researchers to identify key trajectories for further investigation, to corroborate results from other techniques, to seek data of a greater historical reach and to illustrate changes to all audiences.

Understanding ES change from a community perspective gives valuable insights into the relationship between ecosystem functions and human well-being and livelihoods. While participants' observations of ES change might be varied or lacking full explanations, they can help us advance our understanding of ES changes and their impacts. They help correct the picture of SNPBZ as a role model for conservation estates globally while fostering wider discussion of its conservation policies, a potential ES-management scheme and the reality of the park as a highly impacted landscape.

\section{Acknowledgements}

The authors wish to thank the participants and the community of the Khumbu; the Dept. of National Parks, Kathamndu; ICIMOD, Kathmandu; Ev-K2CNR, Kathmandu. This research was funded by The Swiss Development Cooperation, supported by research assistants Pemba Yangi Sherpa, Sonam Futi Sherpa, Gyanu Raja Maharjan, Da Yula Sherpa and Pasang Tendi Sherpa. And benefited from discussions with Alton Byers (pers. comm. 2009), Ang Rita Sherpa (pers. comm. 2012), Tengboche Ringboche, Lama Gieshe, Sonam Hishi Sherpa and Tenzing Tashi Sherpa. 


\section{References}

Bass, J.O. 2010. Learning Landscape Change in Honduras: Repeat Photography and Discovery. In: Webb H.R., E.D. Boyer \& M.R. Turner (eds.), Repeat photography: methods and applications in the natural sciences. Washington DC. 275-288.

Bajracharya, S.B., P.K. Mool \& B.R. Shrestha 2007. Impact of Climate Change on Himalayan Glaciers and Glacial Lakes - Case Studies on GLOF and Associated Hazards in Nepal and Bhutan. ICIMOD \& UNEP/ROAP. Kathmandu.

Byers, A.C. 1997. Landscape change in the Sagarmatha (Mt Everest) National Park, Khumbu, Nepal. Himalayan Research Bulletin XVII (2): 31-41.

Byers, A.C. 2005. Contemporary Human Impacts on the Alpine Ecosystems in Sagarmatha (Mt Everest) National Park, Khumbu, Nepal. Annals of the Association of American Geographers 95 (1): 112-140.

Byers, A.C. 2007. An assessment of contemporary glacier fluctuations in Nepal's Khumbu Himal using repeat photography. Himalayan Journal of Sciences 4 (6): 21-26.

Carpenter, S.R. et al. 2009. Science for managing ecosystem services: beyond the millennium ecosystem assessment. The National Academy of Sciences of the USA 106 (5): 1305-1312.

Chan, K.M.A., M.R. Shaw, D.R. Cameron, E.C. Underwood \& G.C. Daily 2006. Conservation planning for ecosystem services. Public Library of Science Biology 4 (11): e379.

Chaudhary, R.P., T.H. Aase, O.R. Vetaas \& B.P. Subbedi (eds.) 2007. Local Effects of Global Changes in the Himalayas: Manang, Nepal. Tribhuvan University, Nepal and University of Bergen, Norway.

Constanza, R. et al. 1997. The value of the world's ecosystem services and natural capital. Nature 387: 253-260.

Daw, T., K. Brown, S. Rosendo \& R. Pomeroy 2011. Applying the ecosystems services concept to poverty alleviation: the need to disaggregate human well-being. Environmental Conservation 38 (4): 370-379.

de Vaus, D. 2001. Research Design in Social Research. London.

Eckholm, P.E. 1976. Losing ground. Environmental stress and world food prospects. New York.

Edwards, D.M. 1996. Non-timber forest products from Nepal: Aspects of the trade in medicinal and aromatic plants. Kathmandu, Nepal: Ministry of Forest and Soil Conservation, Forestry Research and Survey.

Garrard, R. 2010. Landscape dynamics in Sagarmatha (Mount Everest) National Park, Nepal: Impacts on selected environmental services and adaptive capacities. A Ph.D. project. Mountain Research Initiative (MRI) Newsletter 4

Garrard, R., T. Kohler, U. Wiesmann, F.M. Price, A.C. Byers \& A.R. Sherpa 2012. An ever-changing place: interpreting landscape change in Sagarmatha
(Mt Everest) National Park, Nepal: re-photographic survey and encounter. eco.mont 4 (2).

Garrard, R., T. Kohler, U. Wiesmann, F.M. Price, A.C. Byers \& A.R. Sherpa (forthcoming). Interpreting landscape dynamics in Sagarmatha (Mt Everest) National Park: Land use and cover change and surrounding social context.

Grêt-Regamey, A. \& S. Kytzia 2007. Integrating the valuation of ecosystem services into the input-output economics of an Alpine region. Ecological Economics 63: 786-798.

Grêt-Regamey, A., S.H Brunner \& F. Kienast 2012. Mountain Ecosystem Services: Who Cares? Mountain Research and Development 32 (S1): S23-S34.

Gurung, R., N. Ledgard \& F. Klatzel 2010. High Altitude Forestry Manual, Sagarmatha National Park Forestry Project. Sir Edmund Hilary Foundation of Canada, the Himalayan Trust. Kathmandu.

Gurung, S.M. 1989. Human perception of mountain hazards in the Kakani-Kathmandu area: experiences from the middle mountains of Nepal. Mountain Research and Development 9 (4): 353-364.

Harper, D. 2002. Talking about pictures: a case for photo elicitation. Visual studies 17 (1): 13-26.

Hay, L. 2000. Qualitative Research Methods in Human Geography.

Hay, R. 1998. Sense of place in development context. Journal of Environmental Psychology 18: 5-29.

Henderson, K. 1991. Dimensions of Choice: A Qualitative Approach to Recreation, Parks and Leisure Research.

Hewitt, K. 2009. Culture and risk: Understanding the sociocultural settings that influence risk from natural hazards, Synthesis report from a global E-Conference organised by ICIMOD and facilitated by the Mountain Forum Kathmandu, ICIMOD: 14.

HKKH [Hindu Kush - Karakoram - Himalaya] Partnership 2009. Water Quality Improvement in SNPBZ. HKKH Technical Paper.

HKKH [Hindu Kush - Karakoram - Himalaya] Partnership 2010. Visitor Survey in Sagarmatha National Park Autumn 2007 and Spring 2008. HKKH Technical Paper.

Hunziker, M., M. Buchecker \& T. Hartig 2007. Space and Place - two aspects of the human - landscape relationship. In: Kienast, F. S. Ghosh \& O. Wildi (eds.), A Changing World-Challenges for Landscape Research. Landscape Series. Dordrecht, The Netherlands. 47-62.

Hurni, H., U. Wiesmann \& R. Schertenlieb (eds.) 2004. Research for Mitigating Syndromes of Global Change. A Transdisciplinary Appraisal of Selected Regions of the World to Prepare Development-Oriented Research Partnerships. Perspectives of the Swiss National Centre of Competence in Research (NCCR) North-South 1.

IPCC 2007. Impacts, adaptation and vulnerability. Working group II. Contribution to the Intergovernmental Panel on Climate Change. Forth Assessment report. Cambridge UK.

Ives, J.D. 2004. Himalayan Perceptions. Environmental change and the well-being of mountain peoples. 
Ives, J.D. \& B. Messerli 1989. The Himalayan dilemma. London.

Ives, J.D \& B. Messerli 1997. Mountains of the world: a global priority. New York, USA and Carnforth, UK.

Klatzel, F. 2000. Stories and Customs of the Sherpas: as told by Ngawang Tenzin Zangbu, Abbot of Tengboche Monastery. Kathmandu. Nepal.

Körner, C. \& M. Ohsawa (Coordinating Lead Authors) 2005. Mountain systems. In: Hassan, R. et al. (eds.), Ecosystems and Human Well-being: Current State and Trends 1: 681-716. Washington, DC.

Kreutzmann, H. 2009. Transformations of High Mountain pastoral strategies in the Pamirian Knot. Nomadic Peoples 13 (2): 102-123.

Kruger, L. 2005. Community and landscape change in southeast Alaska. Landscape and Urban Planning 72: 235-249.

Lincoln, Y. \& E. Guba 1985. Naturalistic Inquiry. Beverly Hills, CA.

MA [Millenium Ecosystem Assessment] 2003. Ecosystems and Human Well-Being: Current State and Trends. Washington.

May, T. 1997. Social Research, Issues, methods and process. Buckingham, UK

McCracken, G. 1988. The Long Interview. London.

Mool, P.K., S.R. Bajracharya \& S.P. Joshi 2001. Inventory of glaciers, glacial lakes and glacial lake outburst floods: monitoring and early warning systems in the Hindu KushHimalayan region, Nepal. Kathmandu: ICIMOD.

Naidoo, R. et al. 2008. Global Mapping of ecosystem services and conservation priorities. PNAS 105 (28): 9495-9500.

Nepal, K.S., T. Kohler \& R.B. Banzhaf 2002. Great Himalaya: Tourism and the Dynamics of Change in Nepal. Swiss Foundation for Alpine Research,Switzerland.

NPC 2011. Nepal Status Paper - United Nations Conference on Sustainable Development 2012 (Rio+20) Synopsis. Kathmandu, Nepal: National Planning Commission

Nüsser, M. 2001. Understanding cultural landscape transformation: a re-photographic survey in Chitral Eastern Hindukush, Pakistan. Landscape and Urban Planning 57: 241-255.

Ostrom, E. 2000. Collective action and the evolution of social norms. The Journal of Economic Perspectives 14 (3): 137-158.

Oven, K., D.N. Petley, J. Rigg, C. Dunn \& N. Rosser 2008. Landslides, livelihoods and risk: vulnerability and decision-making in Central Nepal. In: Casagli, N., R. Fanti \& V. Fanti (eds.), Proceedings of first world landslide forum, Tokyo, Japan 2008: 236-240.

Price, M.F. (ed.) 2006. Global Change in Mountain Regions. Duncow.

Rasul, G., N. Chettri \& E. Sharma 2011. Framework for valuing ecosystem services in the Himalayas. Kathmandu: ICIMOD.

Salemo, F. et al. 2010. Energy, Forest and Indoor Air Pollution Models for Sagamatha National Park and Buffer zone Nepal, Implementation of a Partici- patory Modelling. Mountain Research and Development 30 (2): 113-126.

Schindler, B., M. Brunson \& G. Stankley 2002. Social acceptability of forest conditions and management practices: a problem analysis. Forest Service, Pacific Northwest Research Station, General Technical Report USDA Available at: www.fs.fed.us/pnw/pubs/pnw_gtr537. pdf (accessed 15/03/12)

Sharma, K.S., P. Manandhar \& S.R. Khadka 2010. Political Ecology of Everest Tourism. Forging links to Sustainable Mountain Development.

Sherpa, L.N. 1998. Effects of forest land use on structure and distribution patterns of High-altitude forests: A case study of Nangpa and Hinku Valley, Northern Solukhumbu. PhD dissertation at the University of Washington, Seattle.

Sherpa, Y.D. \& R.B Kayastha 2009. A Study of Livestock Management Patterns in SNPBZ: Trends as affected by socioeconomic factors and Climate Change. Kathmandu University Journal of Science, Engineering and Technology 5 (2): 110-120.

Smadja, J. 2009. Reading Himalayan Landscapes over time. Environmental Perception, Knowledge, and Practise in Nepal and Ladakh. Paris.

SNPBZ Management Plan (2006-2011) Sagarmatha National Park Office, Namche VDC, Solukhumbu, Nepal.

Stevens, S.F. 2003. Tourism and deforestation in the Mt Everest region of Nepal. The Geographical Journal. 169 (3): 255-277.

TEEB [The Economics of Ecology and Biodiversity] 2010. Mainstreaming the economics of nature - $A$ synthesis of the approach, conclusions, and recommendations. Available at: http://www.teebweb.org/Portals/25/ TEEB\%20Synthesis/TEEB_SynthReport_09_2010_ online.pdf (accessed 15/03/12)

Thompson, M. 1995. Policy-making in the face of uncertainty: The Himalayas and unknowns. In: Chapman, G.P. \& M. Thompson (eds.), Water and the quest for Sustainable Development in the Ganges Yalley. London.

Turner, W.R. et al. 2012. Global Biodiversity Conservation and the Alleviation of Poverty. BioScience 62: 85-92.

Vuillermoz, E., E. Cabini, P. Verza \& G. Tartari 2006. Pyramid Meteorological Network (PMN) Khumbu Valley, Nepal. Summary Report 1994-2006.

Webb H.R., E.D. Boyer \& M.R. Turner (eds.) 2010. Repeat photography: methods and applications in the natural sciences. Washington DC.

WWF Nepal 2008. Landslide Hazard Zonation Mapping and Vulnerability Assessment along the trekking route from Ghat to Manjo in Solukhumbu District, SNPBZ.

Zierrogel, G. \& R. Calder 2003. Climate variability and rural livelihoods assessing the impacts of seasonal climate forecasts. Royal Geographic Society. Available at: http://uct.academia.edu/GinaZiervogel/ Papers/198981/Climate_Variability_and_Rural_Livelihoods_Assessing_the_Impact_of_Seasonal_Climate_Forecasts_In_Lesotho (accessed 21/03/12) 
Zilberman, D.V. 2007. Payments for environmental services: who gains who loses? Agricultural and Resource Economics Update 11(1): 1-3.

\section{Authors}

\section{Rodney Garrard}

is a $\mathrm{PhD}$ candidate at the Centre for Development and Environment (CDE), University of Bern, Switzerland. His dissertation is exploring landscape dynamics in the Everest region, Nepal: www.garrard.co.nz

Rodney is also a member of the UIAA Mountain Protection Commission; IUCN WCPA Tourism and Protected Areas Group and IUCN's World Commission on Protected Areas (WCPA);

email: rodney.garrard@cde.unibe.ch

\section{Thomas Kohler}

is Associate Director at the Centre for Development and Environment (CDE) and lecturer at the Department of Geography of the University of Bern. He works in the mountains of Eastern Africa and the Horn, the Caucasus, Nepal and Switzerland, with a focus on development dynamics, livelihoods and regional development.

\section{Urs Wiesmann}

has a profound background in research on sustainable regional development. He is Professor in Geography at the University of Bern and co-director of the Centre for Development and Environment (CDE) and of the National Centre of Competence in Research (NCCR) North-South.

\section{Martin F. Price}

is Director of the Centre for Mountain Studies at Perth College, University of the Highlands and Islands, UK, where he holds the UNESCO Chair in Sustainable Mountain Development.

\section{Alton C. Byers}

$\mathrm{PhD}$ is a mountain geographer, climber, and photographer specializing in community-based alpine conservation programs, applied research, and climate change impacts in high altitude mountain regions. He has worked for The Mountain Institute since 1990 and is currently co-manager of the USAID-funded High Mountain Glacial Watershed Program with projects in Nepal, Peru, and Tejikistan.

\section{Ang Rita Sherpa}

is TMI's Senior Program Manager, has more than 20 years of professional experience in the implementation of mountain protected area, ecotourism, community based tourism and sustainable development projects. He graduated from the University of Wales, UK, in 2001 in Protected Area Landscape Management. 